WIDER Working Paper 2020/97

\title{
Globalization and gender inequality
}

Evidence from South Africa

Caro Janse van Rensburg, ${ }^{1}$ Carli Bezuidenhout, ${ }^{2}$ Marianne Matthee, ${ }^{3}$ and Victor Stolzenburg ${ }^{4}$

August 2020 
Abstract: Inequality has been rising in most countries for several decades, with negative consequences for social cohesion and economic growth. Substantial gender wage gaps contribute significantly to overall wage inequality. We look at an often-overlooked driver of gender inequality: international trade. Trading firms constitute 70 per cent of employment in South African manufacturing and, hence, have a large impact on the country's labour dynamics. Using employeremployee matched data on the universe of formal South African manufacturing firms, we show that these firms exhibit greater gender wage gaps than non-traders. The effect seems to be driven by trading firms requiring more flexibility from their workforce in interactions with customers and suppliers across continents and time zones. As women are-or are considered to be-less flexible because of uneven household responsibilities, they receive a lower trading wage premium than men. We find no evidence for other potential channels.

Key words: gender wage gap, international trade, employer-employee matched data, South Africa

JEL classification: F16, J16, J31

Acknowledgements: The authors would like to acknowledge the support of UNU-WIDER, as well as the National Treasury and South African Revenue Services (SARS) for access to the data. Marianne Matthee also acknowledges support from the National Research Foundation (NRF) of South Africa (Grant Number 118762). Any opinion, finding, and conclusion or recommendation expressed in this material is that of the authors, and the NRF does not accept any liability in this regard. Furthermore, any such opinion, finding, and conclusion or recommendation is not intended to represent the positions or opinions of the World Trade Organization (WTO) or its members, and is without prejudice to members' rights and obligations under the W'TO.

\footnotetext{
${ }^{1}$ School of Economics and TELIT-SA (Technology Enhanced Learning and Innovative Education and training in South Africa), North-West University, Potchefstroom, South Africa; corresponding author: Caro.JanseVanRensburg@nwu.ac.za; ${ }^{2}$ School of Economics North-West University, Potchefstroom, South Africa; ${ }^{3}$ Gordon Institute of Business Science, University of Pretoria, Pretoria, South Africa; ${ }^{4}$ Economic Research and Statistics Division, World Trade Organization, Geneva, Switzerland.
}

This study has been prepared within the UNU-WIDER project Southern Africa-Towards Inclusive Economic Development (SA-TIED).

Copyright (C) UNU-WIDER 2020

Information and requests: publications@wider.unu.edu

ISSN 1798-7237 ISBN 978-92-9256-854-2

https://doi.org/10.35188/UNU-WIDER/2020/854-2

Typescript prepared by Luke Finley.

The United Nations University World Institute for Development Economics Research provides economic analysis and policy advice with the aim of promoting sustainable and equitable development. The Institute began operations in 1985 in Helsinki, Finland, as the first research and training centre of the United Nations University. Today it is a unique blend of think tank, research institute, and UN agency — providing a range of services from policy advice to governments as well as freely available original research.

The Institute is funded through income from an endowment fund with additional contributions to its work programme from Finland, Sweden, and the United Kingdom as well as earmarked contributions for specific projects from a variety of donors.

Katajanokanlaituri 6 B, 00160 Helsinki, Finland

The views expressed in this paper are those of the author(s), and do not necessarily reflect the views of the Institute or the United Nations University, nor the programme/project donors. 
South Africa has one of the highest levels of income inequality in the world, according to various measures reported by UNU-WIDER's (2020) World Income Inequality Database. This is a threat to social cohesion and economic growth. High levels of gender inequality can be a significant factor behind aggregate levels of income inequality. In line with this, over the last decade gender equality has become a main focus of the international community. This is most evident in the establishment of UN Women in 2010 and the inclusion of the issue in the UN's Sustainable Development Goals (SDGs) in 2015. Beyond its relevance in the international policy arena, there is a strong economic case for gender equality and women's economic empowerment. According to the McKinsey Global Institute (2015), US $\$ 28$ trillion could be added to global GDP by 2025 if the existing gender gap is overcome.

In the context of trade, gender was put in the spotlight in the WTO's 2017 Buenos Aires Declaration on Women and Trade. As countries develop their strategies to implement the SDGs and monitor progress in relation to the Aid for Trade initiative, it is increasingly important to understand what role trade can play in gender equality. The WTO's (2019) Global Review of Aid for Trade Review of 2019 revealed the rising salience of the trade/gender nexus for development and its heightened prioritization by the donor community.

The impact of trade on gender inequality is multifaceted. Trade can decrease the gender wage gap (GWG) - for instance by shifting resources into female-intensive sectors, which changes relative labour demand in favour of women. It can also decrease the GWG by increasing import competition, which lowers the scope for discrimination. However, trade can also increase the GWG by shifting resources into male-intensive sectors, which similarly changes relative labour demand but in favour of men.

In this paper, we examine the relationship between trade and the GWG but focus on channels that operate at the level of the firm. Trading firms have a significant impact on overall wage inequality and the GWG, since they make up 70 per cent of employment in manufacturing firms in South Africa. Recent research by Boler et al. (2018) on Norwegian firms has highlighted how firm behaviour affects the relationship between trade and gender. They hypothesize that as trading firms require employees to be more flexible because of interactions with foreign suppliers and customers, long and unusual office hours and extensive business travel are implied. As women are perceived to be less flexible than men, trading firms may therefore exhibit a larger GWG. In line with this hypothesis, Boler et al. (2018) find that the GWG of Norwegian manufacturing exporters is higher by about one percentage point once unobserved individual heterogeneity is accounted for.

Using employer-employee matched data for South Africa, we test whether this result holds in a developing-country context. Given the specific circumstances in Norway, it is important to examine whether a similar fact emerges in countries where inequality is much higher to begin with and where trading firms might play a different role. For instance, unlike in a relatively gender-equal society such as Norway, there is the possibility that other channels are more important than workforce flexibility. In particular, manufacturing trade in South Africa and many other developing countries is to a certain extent driven by foreign-owned firms. A recent strand of literature suggests that firms might transfer their corporate culture when they invest abroad. This tends to lead to better working conditions for women in countries with high levels of gender inequality (see, for example, Kodama et al. 2018; Tang and Zhang 2017). Another channel that operates at the firm 
level is profitability, since, with trade, profits tend to go up, increasing the scope for wasteful discriminatory behaviour (Ben Yahmed 2017).

This paper therefore aims to determine whether and by how much trade raises or reduces the overall GWG in a developing-country context by, firstly, identifying whether a differential GWG exists, and if so, secondly, identifying the channel(s) behind it. Our results suggest that firm behaviour in South Africa differs in some respects from firm behaviour in high-income countries but also exhibits important similarities. Most importantly, manufacturing traders in South Africa exhibit an unconditional GWG that is higher by four percentage points. While the earnings of women in non-trading firms are about 64 per cent of those of their male colleagues, the earnings of women in trading firms are only 60 per cent. Once we control for unobserved individual- and firm-level characteristics, such as workers' education or firm size, the difference reduces, but it remains economically meaningful.

Our results regarding the underlying channels suggest that the flexibility mechanism might be dominant in a developing-country context as well. Neither controlling for profitability nor doing so for foreign ownership affect the results regarding the trading status of the firm. In contrast, splitting the sample into workers aged above or below 45 shows that this difference is driven by the younger cohort. This is indicative of the flexibility mechanism, as women are likely to be perceived as more time-constrained when they have school-age children or are of the age to have children. However, further tests regarding the flexibility channel that rely on the assumption that it is more pronounced at higher ends of the wage distribution produce inconclusive results; thus, further research is necessary to understand what drives the differential GWG of traders in the context of South Africa.

This paper contributes to the literature on trade and gender inequality by broadening the scope of the literature on trading firm behaviour to developing countries. Moreover, we expand the literature by using a broader definition of traders that includes also importers. Finally, we add to the literature by looking at globalization more generally by also examining the behaviour of foreignowned companies.

The outline of the paper is as follows: Section 2 provides a brief overview of the literature, Section 3 describes the empirical approach to measuring the effect of trade on the GWG and to capturing the channels behind it, Section 4 outlines the data and presents descriptive statistics, Section 5 contains the results, and Section 6 concludes.

\section{Literature overview}

The GWG is a key determinant of female participation in the labour force. Galor and Weil (1996) show that a smaller gap raises the opportunity costs of women staying outside the labour market and is therefore likely to boost female labour force participation. Extending consideration of female participation in the labour market to include a focus on the international context, empirical studies have been conducted to examine different channels linking trade liberalization to gender (in)equality.

Some early studies highlight the role of increased competition brought about by imports. By empirically testing Becker's (1957) seminal work on the economics of discrimination, which predicts that rising competition will limit the scope for discrimination, a series of papers have shown that increased competition from imports leads to a narrowing of the GWG in concentrated (i.e. non-competitive) industries relative to industries that were competitive before trade 
liberalization (Artecona and Cunningham 2002; Black and Brainerd 2004; Klein et al. 2013). On the export side, studies have revealed that trade can narrow the GWG by inducing a reallocation of resources towards female-intensive comparative-advantage sectors and by incentivizing technological upgrading, reducing the demand for physical tasks that favour male labour (AguayoTellez et al. 2014; Juhn et al. 2014).

However, trade can also lead to a widening of the GWG. For instance, in contrast to imports, exports can reduce competitive pressures by increasing firm profitability, which in turn exacerbates the GWG (Ben Yahmed, 2017). For example, in the case of the North American Free Trade Agreement (NAFTA), the expansion of female-intensive sectors widened the GWG in the US with the dilution of the capital-labour ratio. If women are more complementary to capital than men, a lower capital-labour ratio decreases the relative female marginal productivity (Sauré and Zoabi 2014). Other studies have suggested that trade liberalization can widen the GWG because women have weaker bargaining positions (Berik et al. 2004; Seguino 1997).

In recent research, Boler et al. (2018) highlight a new channel linking trade to the GWG at the firm level. Exporters require more flexibility from their employees than non-exporters, since they deal with customers across time zones, often necessitating long business travel times and unusual business hours. Women are usually perceived to be less flexible than men, since they tend to be responsible for a larger share of domestic activities such as child-rearing. As a result, trading firms might exhibit a wider GWG, and since trade liberalization shifts resources to exporters it could widen the GWG. In line with this channel, Boler et al. (2018) observe that Norwegian exporters exhibit a narrower unconditional GWG than non-exporters, but a wider GWG once unobserved, individual heterogeneity is accounted for. This implies that Norwegian exporters employ highly skilled women whose productivity is not fully reflected in the data. Therefore, the relatively less equal behaviour of exporters only shows once these unobserved characteristics are taken into account.

A related strand of recent literature has examined how another aspect of globalization, namely foreign direct investment (FDI), affects gender inequality. This literature shows that women benefit from FDI that comes from countries with lower gender inequality in terms of higher employment shares and better working conditions (Kodama et al. 2018; Tang and Zhang 2017). Interestingly, however, the literature also points to larger GWGs in foreign-owned firms relative to firms with domestic ownership (Magda and Salach 2019; Vahter and Masso 2019). This would in fact also be in line with the flexibility channel described by Boler et al. (2018), since employees of foreign-owned firms are also likely to be required to travel more and to be available during the office hours of their holding firm.

Over and above the literature on globalization and the GWG, this paper draws on a substantial body of research on wage differentials between traders and non-traders. This line of inquiry has established that exporters pay a significant wage premium, which shrinks but remains significant when both observed and unobserved firm and worker characteristics are accounted for (Bernard et al. 1995; Irarrazabal et al. 2013). Bezuidenhout et al. (2018) find that this pattern also emerges among South African manufacturers. In this regard, Martins and Opromolla (2011) highlight that it is important to also account for the importing activity of firms to avoid attributing effects solely to exporting. 
There are mixed findings for the GWG in South Africa since 1995. On the one hand, Muller (2009) and Kollamparambil and Razak (2016) ${ }^{1}$ find that the overall GWG has narrowed over time since democracy. Bhorat and Goga (2012) find a decline in the unconditional GWG, but not in the conditional GWG. Ntuli (2007), on the other hand, finds that the GWG increased between 1995 and 2004. Our calculation of an unconditional wage gap also shows that there is an increase in the GWG between 2010 and 2016 (see Figure 2). Mosomi (2019), using the Post-Apartheid Labour Market Series dataset, concludes that the GWG is heterogeneous across the wage distribution. In particular, she finds that the GWG is narrower at the bottom percentiles of the wage distribution, but higher towards the top of the wage distribution, indicating a glass ceiling effect for women at this distribution range.

There have been very few studies linking the GWG to international trade in the South African context. Export growth in South Africa has been encouraged since the country's trade liberalization process during the 1990s. The then new government restructured labour laws to specifically encourage women's participation in the labour market. These, together with increased participation in globalization, have improved the labour force participation of women in the economy (Lepelle et al. 2017). This corroborates Thurlow's (2006) findings that trade liberalization contributed to a decline in the GWG between 1995 and 2003 (overall employment in the manufacturing sector also reduced over this period).

Lepelle et al. (2017) note that although South African studies have emerged on the gender-specific effects of trade, there are still several shortcomings, one being that these studies have been conducted on an aggregate (national) level. Although Lepelle et al.'s (2017) study contributes to the understanding of these trade and gender issues on a more detailed (i.e. regional) level, it is imperative to provide an even more detailed analysis by considering the gender-specific effects of trade on an employer-employee level. Indeed, Ebrahim and Lilenstein (2019: 16) call for such research to evaluate 'the extent to which trade can create opportunities or improve employment for women', especially as a gender variable has subsequently been included in updated versions of the South African Revenue Services (SARS) administrative data. As such, we provide, in a previous preliminary study, evidence that both men and women in trading firms earn more than their counterparts in non-trading firms, but that the GWG is greater for trading firms (Bezuidenhout et al. 2019). Considering this, in the sections below we further explore the differential GWG of traders and the channel(s) behind it.

\section{$3 \quad$ Empirical approach}

In order to determine whether a firm's trading status influences the GWG in South Africa, we follow Boler et al. (2018). This means that we estimate a Mincerian (Mincer 1974) wage equation, controlling for the available individual characteristics of age, age squared, and gender, as well as a dummy capturing whether the individual works for a firm that imports and/or exports. We then add increasingly more stringent fixed effects to account for characteristics that are not observable in the data but are likely to cause an omitted-variable bias. The following equation is specified as the baseline equation:

\footnotetext{
1 Muller (2009) shows a reduction in the GWG between 1995 and 2006, especially for part-time workers. Kollamparambil and Razak (2016) find that the GWG narrowed between 2001 and 2006.
} 
$\ln w_{i j s t}=\beta_{1}$ fem $_{i}+\beta_{2}$ fem $_{i} *$ trade $_{j t}+\beta_{3}$ trade $_{j t}+\beta_{4} a g e_{i t}+\beta_{5} a g e_{i t}^{2}+\varepsilon_{i j s t}$

where $w_{i j s t}$ is the monthly income of worker $i$ employed by firm $j$ in industry $s$ at time $t$; fem $i$ is a dummy variable equal to one for female workers; and trade $_{j t}$ is a dummy variable equal to one if the firm imports, exports, or does both.

$\beta_{2}$ in Equation 1 provides us with insights into the effect that the trading status of a firm has on the GWG by stating the differential GWG of trading firms compared with non-traders, conditional on an employee's age. This difference in the GWG between trading and non-trading firms could, however, be driven by variables that are related to both the trading status of a worker's firm and its wages but that are not included in Equation 1. For example, if women are predominantly employed in low-wage industries that do not trade internationally, then the results would show a high GWG that would be attributable to a clustering of genders around certain industries rather than to the trading status of the firm. Therefore, in Equation 2 we add industry-year fixed effects, $\alpha_{s t}$, to Equation 1 in order to avoid this sectoral selection bias and to control for time trends. Equation 2 is then specified as: ${ }^{2}$

$\ln w_{i j s t}=\beta_{1}$ fem $_{i}+\beta_{2}$ fem $_{i} *$ trade $_{j t}+\beta_{3}$ trade $_{j t}+\beta^{\prime} X_{i t}+\alpha_{s t}+\varepsilon_{i j s t}$

Equation 2 accounts for gendered groupings across industries but not across individuals within firms. Previous studies on the subject have highlighted that individuals with certain characteristics, such as better skills or more education, self-select into trading firms. ${ }^{3}$ If this leads to differences in the gender skill gap between trading and non-trading firms, it could explain a differential GWG between firms that trade and firms that do not as being due to skills or education rather than trade. ${ }^{4}$ To account for this, we also add an individual fixed effect, $\alpha_{i}$. This allows us to control for unobserved individual characteristics while still avoiding the gender composition biases across industries as well as time trends as discussed above: ${ }^{5}$

$\ln w_{i j s t}=\beta_{1}$ fem $_{i}+\beta_{2}$ fem $_{i} *$ trade $_{j t}+\beta_{3}$ trade $_{j t}+\beta^{\prime} X_{i t}+\alpha_{s t}+\alpha_{i}+\varepsilon_{i j s t}$

The broader literature on the wage premium of trading firms has also identified various firm characteristics that lead to differences in the wage structure of traders, such as firm size and productivity. It is thus possible that a part of the gender wage differential between trading and non-trading firms that is visible in Equations 1 to 3 is due to such firm characteristics. For instance, if larger firms have a finer division of labour and assign women predominantly to lower-paid activities, $\beta_{2}$ will be biased, since trading firms tend to be large. To control for this and to make the estimation as conservative as possible, in Equation 4 we merge the employee fixed effects with employer fixed effects into an employee-employer, or job-spell, fixed effect, $\alpha_{i j}$. This has the advantage that identification stems exclusively from workers within a firm that switched its status from non-trading to trading while holding a firm's workforce composition constant. This avoids a potential bias stemming from firms adjusting their workforce composition when starting to trade,

\footnotetext{
${ }^{2}$ For conciseness, from here on we summarize age and age squared in the vector $X$.

${ }^{3}$ See Bernard et al. (2007) for a review of this literature.

${ }^{4}$ For instance, in the study by Boler et al. (2018) it was found that Norwegian exporters employ more highly skilled women relative both to the men they employ and to the women employed by non-exporters. As a result, controlling for education caused the initially smaller GWG of exporters to become larger than that of non-exporters.

${ }^{5}$ The new fixed effect absorbs the female dummy such that from Equation 4 on, we can no longer identify the level of the GWG.
} 
and identifies only differences in wage changes for men and women who have worked for newly trading firms before and after it started to trade: ${ }^{6}$

$$
\ln w_{i j s t}=\beta_{2} \text { fem }_{i} * \operatorname{trade}_{j t}+\beta_{3} \text { trade }_{j t}+\beta^{\prime} X_{i t}+\alpha_{s t}+\alpha_{i j}+\varepsilon_{i j s t}
$$

We consider that the fixed effects effectively control for omitted-variables bias, allowing us to discuss the role of trade in gender inequality and broader inequality in a developing-country context.

\subsection{Identifying the channels behind our results}

To effectively address potential negative effects, or utilize potential positive effects, of trade, it is necessary for policy makers to understand what are the exact channels behind the trade-GWG relationship. In order to shed light on this, we perform several additional analyses. In particular, we re-estimate variations of benchmark Equation 4 that can inform us on the underlying mechanisms.

We start by including a dummy variable that captures whether a firm is foreign-owned or not, foreign $_{j t}$. This tells us whether the influence that the trading status of the firm has on the GWG is due to a foreign corporate culture that has been adopted in the firm. As discussed in Section 2, recent studies have shown that foreign investors tend to introduce their corporate culture in foreign affiliates, including the working conditions of women. We consider this to be of particular importance in a developing-country context, as the differences between the corporate cultures of foreign investors and domestic firms might be larger and as FDI plays a larger role in trade. We thus estimate the following equation:

$$
\begin{aligned}
& \ln w_{i j s t}=\beta_{2} \text { fem }_{i} * \text { trade }_{j t}+\beta_{3} \text { trade }_{j t}+\beta_{4} \text { fem }_{i} * \text { foreign }_{j t}+\beta_{5} \text { foreign }_{j t}+\beta^{\prime} X_{i t}+ \\
& \alpha_{s t}+\alpha_{i j}+\varepsilon_{i j s t}
\end{aligned}
$$

We then further investigate the cause behind the influence of the trading status of firms by controlling for the profitability of the firm, rrofit $_{j t}$. Firms that are more profitable may be able to afford to discriminate more, if discrimination is taste-based (Becker 1957). As trade increases profitability, this channel could drive the observed differential GWG. This leads to the following equation:

$$
\begin{aligned}
& \ln w_{i j s t}=\beta_{2} \text { fem }_{i} * \text { trade }_{j t}+\beta_{3} \text { trade }_{j t}+\beta_{4} \text { fem }_{i} * \text { foreign }_{j t}+\beta_{5} \text { foreign }_{j t}+ \\
& \beta_{6} \text { fem }_{i} * \text { profit }_{j t}+\beta_{5} \text { profit }_{j t}+\beta^{\prime} X_{i t}+\alpha_{s t}+\alpha_{i j}+\varepsilon_{i j s t}
\end{aligned}
$$

Finally, we attempt to analyse the flexibility channel by limiting the regression to employees that are either above or below 45 years of age, since perceived flexibility gaps might be most strongly associated with women who have or could have small children:

\footnotetext{
${ }^{6}$ Boler et al. (2018) additionally include an equation that controls for job spell-time fixed effects. Since our panel data cover significantly fewer years, we do not have enough variation over time to implement this step. However, we consider this additional control negligible in terms of identification, since it only additionally controls for changes at the level of the firm that happen simultaneously with the change in trading status and are correlated with both the trading status and the GWG but are not driven by changes in the trading status.
} 


$$
\begin{aligned}
& \ln w_{i j s t}=\beta_{2} \text { fem }_{i} * \text { trade }_{j t}+\beta_{3} \text { trade }_{j t}+\beta^{\prime X} X_{i t}+\alpha_{s t}+\alpha_{i j}+\varepsilon_{i j s t} \text { if age } \text { at }_{i t} \leqq 45 \\
& \ln w_{i j s t}=\beta_{2} \text { fem }_{i} * \text { trade }_{j t}+\beta_{3} \text { trade }_{j t}+\beta^{\prime X} X_{i t}+\alpha_{s t}+\alpha_{i j}+\varepsilon_{i j s t} \text { if age } \text { a }_{i t}>45
\end{aligned}
$$

These auxiliary regressions enable us to understand better why traders might have a different GWG than non-traders, and they can, as a result, lead to better policy advice.

\section{$4 \quad$ Data and descriptives}

\subsection{Data}

Empirical literature examining the wage differentials among trading and non-trading firms have largely been based on plant- or firm-level data, which allows for the control of observable (and unobservable) firm characteristics. Increasingly, a stronger emphasis is being placed on employeremployee matched data vis-à-vis more aggregate datasets. Matched employer-employee data take individual or worker characteristics into account and make it possible to track workers over time (Hummels et al. 2016). However, evidence from these datasets (considering wage differentials among trading and non-trading firms as well as the GWG) are largely from developed-country contexts (e.g. Boler et al. 2018; Martins and Opromolla 2009; Schank et al. 2007), as such datasets are rare in developing countries. Evidence from developing countries on individual or worker characteristics has been based on survey data: see for example Fafchamps' (2009) study on Moroccan firms and Rankin and Schöer's (2013) utilization of the World Bank's 2004 Investment Climate Assessment Survey on South Africa.

In South Africa, great strides have been made to enrich our understanding of a developing-country context through the collaboration between the United Nations University World Institute for Development Economics Research (UNU-WIDER) and South Africa's National Treasury and SARS (Pieterse et al. 2016). This collaboration has enabled researchers to construct an employeremployee dataset, the CIT-IRP5 panel, using pay roll tax data (IRP5), corporate income tax (CIT) returns data, customs data, and VAT data (all of which are made available by SARS). The regressions were run on version 3.4 of the CIT-IRP5 panel (National Treasury and UNU-WIDER 2019a), as well as version 0.6 of the IRP5 dataset (National Treasury and UNU-WIDER 2019b), which was accessed in November of 2019. The descriptives were done with version 3.5 of the CIT-IRP5 panel (National Treasury and UNU-WIDER 2020) and version 0.6 of the IRP5 dataset, accessed in February of 2020. This unique dataset makes it possible to research the individual characteristics that contribute to the gender wage gap, and not only the firm characteristics. As Ebrahim and Lilenstein (2019: 16) point out: 'The tax data allows for firm-level employment behaviour to be examined. Combined with the customs data, there is scope for an evaluation of the extent to which trade can create opportunities or improve employment for women.' Details of how we utilize this unique dataset to consider the GWG are set out below. Table A1 in the Appendix also provides a detailed description of the variables used in the regressions.

From the IRP5 certificates we create a 'weighted monthly income per employee' variable for gender, and calculate the employee's age. The monthly income per employee is calculated by dividing the income by the number of days worked to get the daily wage equivalent. The daily wage equivalent is then multiplied by 30 to get the monthly wage equivalent. Only working-age adults between the ages of 15 and 65 are included in our dataset: all observations outside this range were dropped. Unfortunately, the data are limited in terms of the individual characteristics that are available, resulting in us being unable to observe the education level of the employees. In terms of identification this does not cause a problem, since we can use employee fixed effects, but it limits 
our ability in terms of interpretation, since we cannot observe which individual characteristics affect the results. From the customs data, information on a firm's trading status is obtained, i.e. whether the firm trades internationally (exports and/or imports) or not. Only firms that traded more than ZAR10,000 per year are defined as trading. CIT returns data provide firm characteristics such as firm profitability (which is calculated as a ratio of the firm's cost of sales to its sales) and also whether a firm is foreign- or domestically owned. The foreign ownership variable is a binary variable set to 1 if the ultimate holding company is a foreign firm. All other observations, including missing observations, are set to 0 . This generates a share of foreign-owned firms that is very close to the share indicated in the only other South African dataset providing information on foreign ownership, namely the 2007 World Bank Enterprise Survey dataset for South Africa.

Our final panel dataset ultimately consists of more than 6.5 million observations for all manufacturing firms in South Africa matched with their employees from 2010 to $2016 .{ }^{7}$

\subsection{Descriptive statistics}

Before discussing the results of our estimation work, we present some basic descriptive statistics that motivate our analysis. Table 1 shows the mean income and mean age disaggregated by firm trading type and gender. It also shows the male-female composition within each firm type, the gender distribution across firm types, and the total share of each firm type in the entire manufacturing labour force. Trading firms are the largest employer (70 per cent) in the manufacturing sector of South Africa. This provides a strong case for examining the role of trading firms in gender inequality. Trading firms also tend to employ more women than non-trading firms. There is evidently a large unconditional GWG, with women earning on average less than men in each firm type. Moreover, trading firms pay higher wages on average, but they also have a larger GWG than non-trading firms. A visual depiction of this unconditional GWG can be seen in Figure 1.

Table 1: Descriptive statistics by firm trading type

\begin{tabular}{|c|c|c|c|c|c|c|}
\hline & \multicolumn{2}{|c|}{ Non-trader } & \multicolumn{2}{|c|}{ Trader } & \multicolumn{2}{|c|}{ Total } \\
\hline & Male & Female & Male & Female & Male & Female \\
\hline $\begin{array}{l}\text { Mean income (current } \\
\text { ZAR) }\end{array}$ & $12,502.56$ & $7,941.68$ & $23,250.55$ & $14,018.11$ & $19,919.09$ & $12,245.56$ \\
\hline Mean age & 38 & 39 & 39 & 38 & 38 & 38 \\
\hline $\begin{array}{l}\text { Gender share within } \\
\text { firm type }\end{array}$ & 69 & 31 & 67 & 33 & 68 & 32 \\
\hline $\begin{array}{l}\text { Gender distribution } \\
\text { across firm types }\end{array}$ & 21 & 9 & 47 & 23 & 68 & 32 \\
\hline $\begin{array}{l}\text { Total share in labour } \\
\text { force }\end{array}$ & & 30 & & 70 & & 100 \\
\hline Observations & $1,381,450$ & 624,180 & $3,075,400$ & $1,515,549$ & $4,456,850$ & $2,139,729$ \\
\hline
\end{tabular}

Source: authors' construction based on SARS data (pooled data 2010-16) (National Treasury and UNU-WIDER 2019b, 2020).

\footnotetext{
${ }^{7}$ Summary statistics for our main variables are provided in Table A2 in the Appendix.
} 
Figure 1 shows women's income as a percentage of men's income for manufacturing firms in South Africa across trading types. On average, women's wages are equal to only 61 per cent of men's wages, which puts the unconditional GWG at 39 per cent. Trading firms have a more unequal income distribution between genders, with women earning only 60 per cent of what men earn. In non-trading firms, women earn 64 per cent of what men earn. Thus, trading firms increase South Africa's manufacturing GWG by four percentage points, or about 11 per cent.

Figure 1: Female income as a percentage of male income by firm trading status

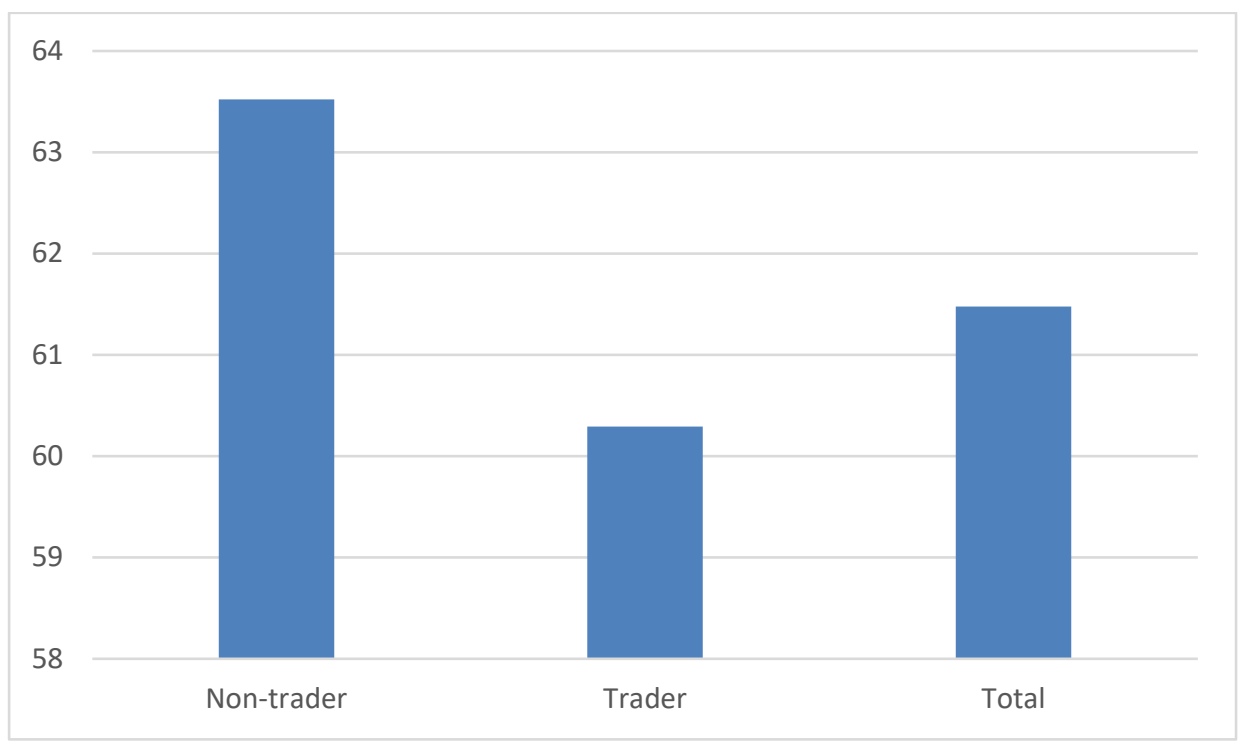

Source: authors' illustration based on SARS data (pooled data 2010-16) (National Treasury and UNU-WIDER 2019b, 2020).

Figure 2 illustrates the unconditional GWG for manufacturing firms in South Africa from 2010 to 2016 together with South Africa's trade openness. The two variables have a large positive correlation of 0.5 , which can be seen as a first indication that trade may contribute to a higher GWG. This is an interesting observation but does not provide us with any insights as to what could be contributing to the trend or whether it could be considered causal. A link between the GWG and the trading status of firms in South Africa has been already established by Bezuidenhout et al. (2019), but only the rigorous empirical approach described in the previous section allows us to identify a causal effect. 
Figure 2: The unconditional GWG of manufacturing firms (current ZAR) and trade openness

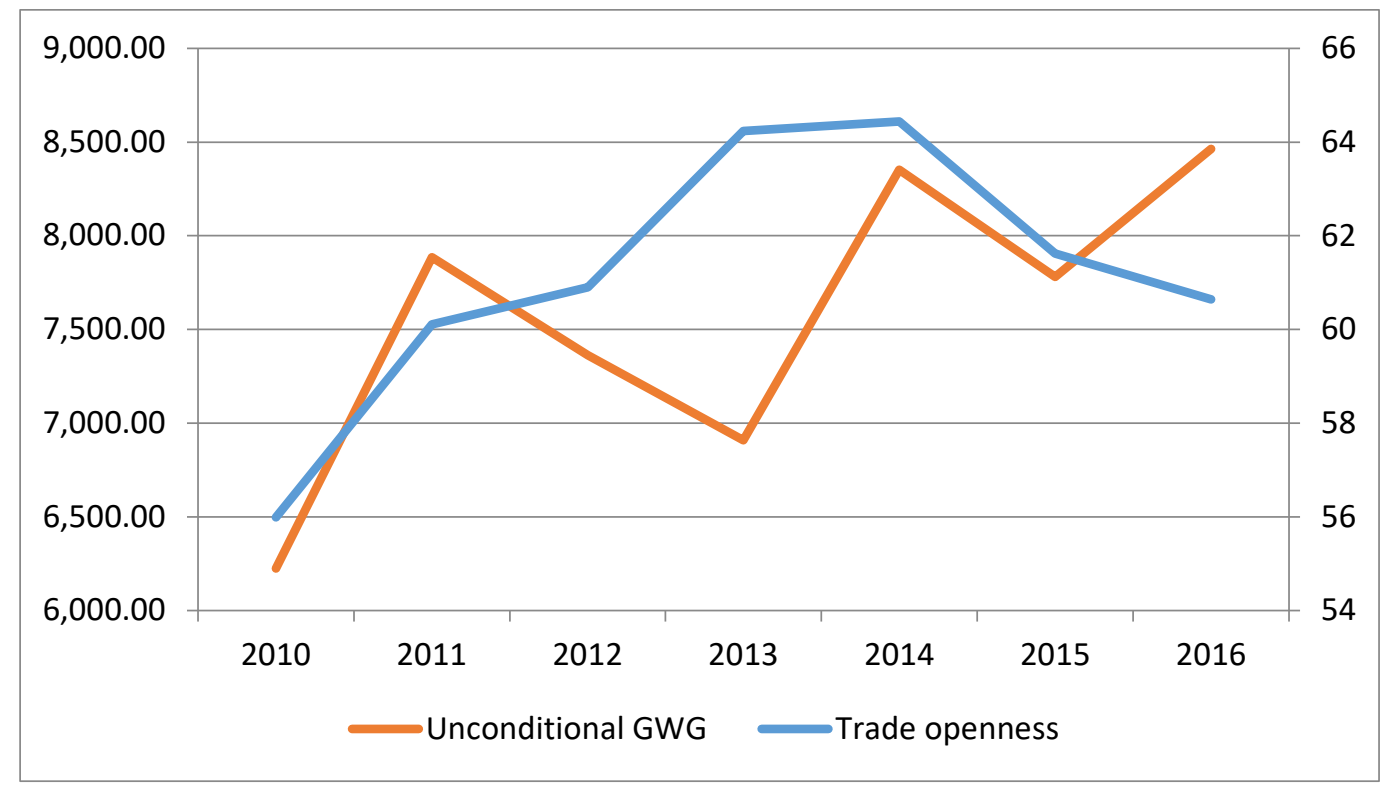

Source: authors' illustration based on SARS data for the unconditional GWG (National Treasury and UNUWIDER, 2019a, b) and World Development Indicators data for trade openness defined as trade/GDP (World Bank 2019).

Finally, Figure 3 presents the share of female employment in manufacturing firms for each income quintile of the employees, disaggregated by trading status. It is not surprising to see that with each subsequent quintile the share of women, in both trading and non-trading firms, decreases. Trading firms employ a greater share of women except at the fifth quintile, where traders and non-traders employ roughly the same share of women, suggesting that women face larger barriers in trading firms when entering the top income quintile. This is evidence that trading firms' requirements for managers are more gender-biased than those of non-trading firms. Requirements regarding flexibility could be an important factor here, since business travel and customer contact is likely to be more frequent in higher wage quintiles.

Figure 3: Share of female employment for manufacturing firms by income quintile and trading status

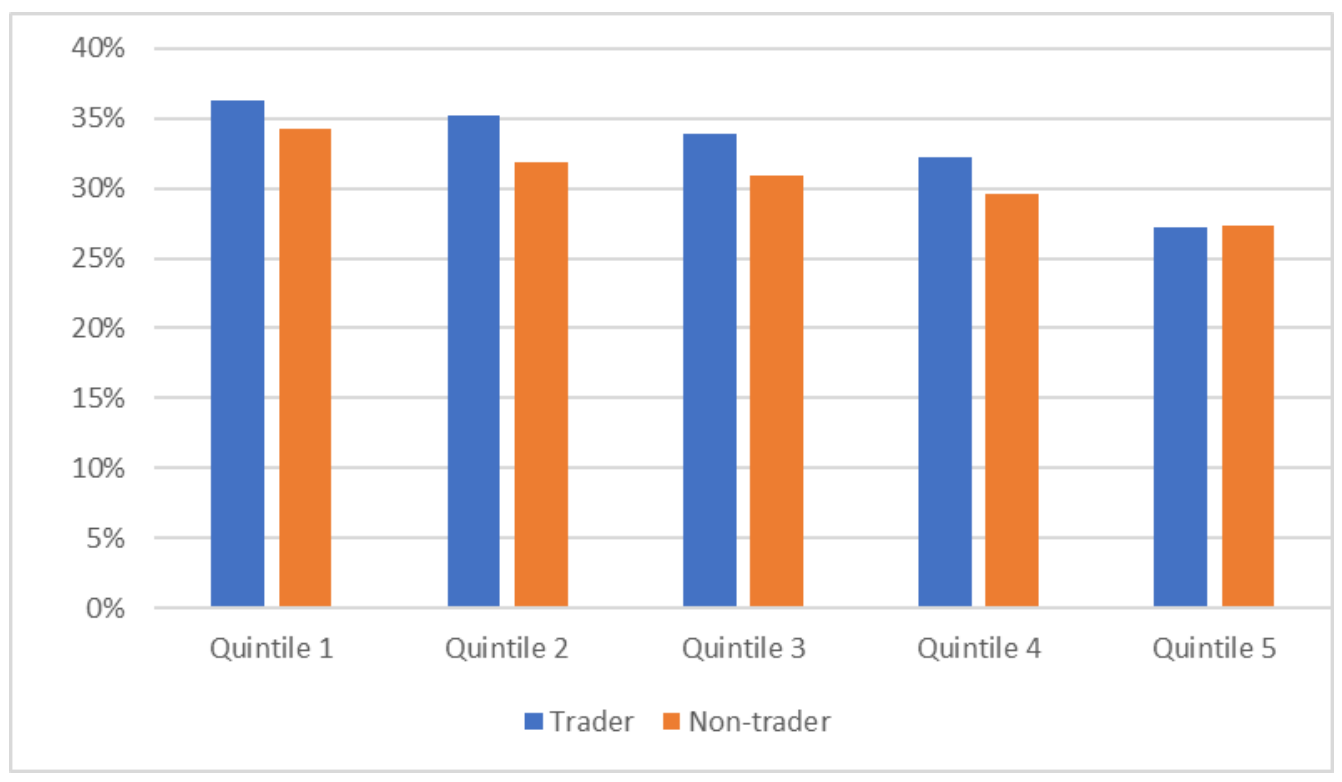

Source: authors' illustration based on SARS data (pooled data 2010-16) (National Treasury and UNU-WIDER 2019b, 2020). 


\subsection{Baseline results}

We now turn to the results of the empirical approach introduced in Section 3 to see whether the descriptive statistics of the previous section represent a stable and robust relationship between trade and the GWG at the firm level. To preview the key findings, we show that firms engaged in international trade pay a significant wage premium to their employees, but that this premium is considerably smaller for women. As a result, trading firms exhibit a larger GWG than non-trading firms.

Column 1 of Table 2 presents the results of the most basic regression (Equation 1), which controls only for age and age squared and is thus close to the unconditional wage gap statistics presented in Section 4.2. It corroborates the well-known facts that a large wage premium is associated with trade (56 per cent for men), and that a similarly large GWG of 33.5 per cent exists in non-trading firms. Most importantly for our purposes, this basic set-up indicates that trading firms exhibit a GWG that, at 37.5 per cent, is four percentage points larger than the GWG of firms that do not trade. Controlling additionally for industry-year fixed effects to account for gender segregation across industries in Column 2, we find that the differential GWG of traders decreases slightly but remains statistically significant (at the 10 per cent level) and substantial.

This is interesting also when compared with the findings of the Norwegian study (Boler et al. 2018) in which the unconditional GWG of exporters was smaller than that of non-exporters and only became larger when controlling for individual level fixed effects. The difference highlights the need to look at this issue in a developing-country context, because it indicates that the underlying drivers behind the relationship between trade and gender are different for developing countries.

Thus, in Column 3 we also add individual fixed effects to test whether certain characteristics of workers in trading firms differ from characteristics of workers in non-trading firms. If, for instance, the education or skills gap between men and women is larger in trading firms than in non-trading firms, this could explain to some extent why the GWG of traders is larger. Indeed, we find that the coefficient for the differential GWG of traders decreases substantially with this additional control, to only half of the previous difference. We also observe that the aggregate trading wage premium drops to about one-sixth of the premium conditional only on industry-year fixed effects.

While our data do not allow us to say which individual characteristic is responsible for this result, we consider that trade is skill-intensive and time-intensive, since it requires products to be competitive at world markets and requires additional skills and flexibility related to interactions with foreign customers and suppliers, such as foreign language skills. However, access to education in many developing countries is still worse for girls than for boys, and gender education gaps tend to be large. Even in developed countries there exist gender gaps with respect to certain traderelated skills in the fields of science, technology, engineering, or mathematics (WBG and WTO 2020). Similarly, flexibility gaps exist across the world, as women still shoulder the majority of domestic responsibilities (WBG and W'TO 2020). Such skills and flexibility gaps could discriminate against women in trading firms and explain larger GWGs. In the next subsection, we examine the extent to which this is the case for flexibility gaps.

The results from our baseline regressions stand also in contrast to the findings for Norway, where the gender skills gap of exporters was smaller rather than larger (Boler et al. 2018), once again highlighting the need for a study in a developing-country context. 
Table 2: Differences in the GWG of trading and non-trading firms

\begin{tabular}{|c|c|c|c|c|}
\hline $\begin{array}{l}\text { Dependent variable: } \\
\text { monthly income }\end{array}$ & $\begin{array}{r}\text { No fixed } \\
\text { effects }\end{array}$ & $\begin{array}{l}\text { Industry-year } \\
\text { fixed effects }\end{array}$ & $\begin{array}{r}\text { Industry-year and } \\
\text { individual fixed effects }\end{array}$ & $\begin{array}{l}\text { Industry-year and job- } \\
\text { spell fixed effects }\end{array}$ \\
\hline Female & $\begin{array}{r}-0.408^{\star \star *} \\
(0.019)\end{array}$ & $-0.298^{\star \star \star}(0.018)$ & - & \\
\hline Trading firms & $\begin{array}{r}0.448^{\star \star *} \\
(0.053)\end{array}$ & $0.363^{\star \star \star}(0.029)$ & $0.059^{\star \star *}(0.006)$ & $0.025^{\star \star \star}(0.006)$ \\
\hline Female * trading firms & $\begin{array}{r}-0.060^{\star *} \\
(0.030)\end{array}$ & $-0.048^{*}(0.028)$ & $-0.024^{\star \star \star}(0.009)$ & $-0.018^{\star \star}(0.007)$ \\
\hline $\begin{array}{l}\text { Industry-year fixed } \\
\text { effects }\end{array}$ & No & Yes & Yes & Yes \\
\hline Employee fixed effects & No & No & Yes & No \\
\hline $\begin{array}{l}\text { Employee-employer } \\
\text { fixed effects }\end{array}$ & No & No & No & Yes \\
\hline Observations & $6,596,175$ & $6,596,175$ & $5,995,848$ & $5,751,561$ \\
\hline $\mathrm{R}^{2}$ & 0.1491 & 0.252 & 0.494 & 0.90 \\
\hline
\end{tabular}

Note: standard errors in parentheses clustered at the level of the firm. Additional controls include age and age squared. ${ }^{* \star *} p<0.01,{ }^{* \star} p<0.05,{ }^{*} p<0.1$. As we increase the dimensions of our fixed effects, we lose some observations as they become multi-collinear with the fixed effects. This can occur when individuals appear only for one year in the data (Column 3) or when a worker-firm pair appears only for one year in the data (Column 4).

Source: authors' construction based on SARS data (National Treasury and UNU-WIDER 2019a, b).

Finally, to exclude the possibility that our results are driven by changes in the workforce composition of trading firms around the time of their becoming traders, we combine the individual and firm fixed effects into a job-spell fixed effect in Column 4. This identifies the effect exclusively based on workers who worked for firms which had changed their trading status already before and after they started to trade. This eliminates selection effects and is our preferred specification. The additional GWG of traders decreases only slightly to 1.8 percentage points and remains statistically significant at the 5 per cent level.

\subsection{Results for the underlying channels}

In order to understand the underlying mechanism behind this effect, in Table 3 we re-estimate variants of Equation 5 that can inform us about three potential drivers of the differential GWG. In Columns 2 and 3, we test the flexibility channel by splitting the sample into workers over and under 45 as a form of placebo check. Since differences in flexibility between men and women should be larger when women are at the age at which they (can) have young children, the effect should be smaller and eventually disappear at older ages. In line with this, we observe in Column 2 that the coefficient for the differential GWG of traders almost halves in size and becomes statistically insignificant for workers above 45 while, in Column 3, it is almost identical to the fullsample coefficient for workers below 45 .

In Columns 4 and 5, we test whether foreign-owned or more profitable firms exhibit differential GWG, and whether this affects the coefficient for trading firms. Both of these characteristics are strongly correlated with a firm's trading status and ARE thus potential sources of biases. In Column 5, where we control for both factors simultaneously, we find that profitability does not affect the GWG, while foreign ownership increases the GWG similarly to trading status. Importantly, the coefficient for the differential GWG of traders is hardly affected by these controls. It seems therefore that the endogeneity of trading status, at least in these two dimensions, is not biasing the results. 
Table 3: Testing channels behind differences in the GWG of trading and non-trading firms

\begin{tabular}{|c|c|c|c|c|c|}
\hline $\begin{array}{l}\text { Dependent variable: } \\
\text { monthly income }\end{array}$ & $\begin{array}{r}\text { Benchmark } \\
\text { (1) }\end{array}$ & $\begin{array}{r}A g e ́ \geq 45 \\
(2)\end{array}$ & $\begin{array}{r}\text { Age }<45 \\
(3)\end{array}$ & $\begin{array}{r}\text { Foreign } \\
(4)\end{array}$ & $\begin{array}{r}\text { Profit } \\
(5)\end{array}$ \\
\hline Female & - & - & - & - & - \\
\hline Trading firms & $0.025^{\star \star \star}(0.006)$ & $\begin{array}{l}0.017^{\star *} \\
(0.007)\end{array}$ & $\begin{array}{r}0.019 * \star * \\
(0.007)\end{array}$ & $\begin{array}{r}0.026^{\star \star *} \\
(0.001)\end{array}$ & $\begin{array}{r}0.026^{\star \star \star} \\
(0.001)\end{array}$ \\
\hline Female * trading firms & $-0.018^{\star \star}(0.007)$ & $\begin{array}{l}-0.011 \\
(0.009)\end{array}$ & $\begin{array}{r}-0.017^{* *} \\
(0.009)\end{array}$ & $\begin{array}{r}-0.018^{\star \star \star} \\
(0.003)\end{array}$ & $\begin{array}{r}-0.017^{\star \star *} \\
(0.003)\end{array}$ \\
\hline Foreign & & & & $\begin{array}{r}0.064^{\star \star * *} \\
(0.001)\end{array}$ & \\
\hline Female * foreign & & & & $\begin{array}{r}-0.024^{\star \star \star} \\
(0.002)\end{array}$ & \\
\hline Profit & & & & & $\begin{array}{r}-0.011^{\star \star *} \\
(0.002)\end{array}$ \\
\hline Female * profit & & & & & $\begin{array}{r}-0.007^{\star *} \\
(0.004)\end{array}$ \\
\hline Observations & $5,751,561$ & $1,766,047$ & $3,910,106$ & $5,751,561$ & $5,523,360$ \\
\hline $\mathrm{R}^{2}$ & 0.909 & 0.908 & 0.911 & 0.909 & 0.909 \\
\hline
\end{tabular}

Note: standard errors in parentheses clustered at the level of the firm. Additional controls include age and age squared. ${ }^{* *} p<0.01,{ }^{* *} p<0.05,{ }^{*} p<0.1$.

Source: authors' construction based on SARS data (National Treasury and UNU-WIDER 2019a, b).

This suggests, firstly, that neither the foreign ownership channel nor the profitability channel drive the GWG of trading firms in South African manufacturing. Rather, we take the results for foreign ownership as additional evidence in favour of the flexibility channel, as foreign-owned firms also tend to require their workers to be more flexible, as they might need to travel to the country of the firm's headquarters or communicate with colleagues at the headquarters, which might be in a different time zone. The fact that foreign-owned firms correspondingly also exhibit a larger GWG than non-foreign-owned firms is in this context supportive of the flexibility channel.

\subsection{Robustness tests}

To test the robustness of our results, we change our definition of trading firms, perform additional tests regarding the flexibility channel, and remove or add outliers from the sample. The results for these exercises are shown in Table 4. In Column 2, we report the results for our preferred specification (Equation 4), but the trade dummy is replaced with a trade intensity variable that replicates the standard country-level trade openness indicator at the firm level. This is done by taking the sum of a firm's imports and exports and normalizing it by the firm's sales. ${ }^{8}$ This alternative measure for trading firms captures trade activity better than a simple dummy does, because for some firms trade is key to their business activities while for others it is not. If the larger GWG of traders is really due to trade, we would expect the differential GWG to increase linearly with the importance of trade to the firm. This is exactly what we find in Column 2, where the interaction term is negative and statistically significant at the 5 per cent level.

\footnotetext{
${ }^{8}$ Technically, we proceed by calculating the share of imports in sales and the share of exports in sales and then summing these two shares. This allows us to drop outliers that are likely due to reporting errors. For instance, we observe for some firms that reported exports were larger than reported sales. This could be because customs reporting years and tax reporting years are not identical and the data thus needed to be adapted. However, large discrepancies still remain unlikely. We thus conservatively drop cases where the export ratio was larger than 5 and the import ratio was larger than 10 .
} 
Next, we perform two simple robustness tests in which we vary the sample based on outliers. In Column 4, we drop workers who have reported fewer than three days of work. The daily wages of these workers tend to be extremely high, causing their mean monthly wage equivalents to exceed ZAR1 million, whereas the equivalents for all other reported days never exceed ZAR100,000. We see in Column 4 that this does not have any meaningful impact on the coefficients when compared with the results of our preferred specification in Column 1.

In Column 5, we add firms to the sample that reported very high loss ratios- that is, firms whose reported costs exceeded their sales by a factor of ten. While this could be the case for start-ups, we consider it more likely that these are reporting errors and, therefore, have not included these firms in our profitability results reported previously. Column 4 shows that including them has no impact on the differential GWG of traders but that the profitability coefficients seem unreasonable, with decreases in profitability raising wages and lowering the GWG. This speaks in favour of the assumption that the entries for these firms are false.

Table 4: Robustness tests

\begin{tabular}{|c|c|c|c|c|c|}
\hline $\begin{array}{l}\text { Dependent variable: } \\
\text { monthly income }\end{array}$ & $\begin{array}{r}\text { Benchmark } \\
\text { (1) }\end{array}$ & $\begin{array}{r}\text { Trade } \\
\text { Intensity } \\
(2)\end{array}$ & $\begin{array}{r}\text { Top } 40 \% \\
(3)\end{array}$ & $\begin{array}{r}\text { Wage } \\
\text { outliers } \\
(4)\end{array}$ & $\begin{array}{r}\text { Profit } \\
\text { outliers } \\
(5)\end{array}$ \\
\hline Female & & - & - & - & - \\
\hline Trading firms & $\begin{array}{r}0.025^{\star \star \star} \\
(0.006)\end{array}$ & $\begin{array}{r}0.010 \text { *** } \\
(0.002)\end{array}$ & $\begin{array}{r}0.008 \\
(0.005)\end{array}$ & $\begin{array}{r}0.027^{\star \star \star *} \\
(0.006)\end{array}$ & $\begin{array}{r}0.026^{\star \star \star} \\
(0.007)\end{array}$ \\
\hline Female * trading firms & $\begin{array}{r}-0.018^{\star \star} \\
(0.007)\end{array}$ & $\begin{array}{r}-0.008^{\star *} \\
(0.004)\end{array}$ & $\begin{array}{l}-0.009 \\
(0.006)\end{array}$ & $\begin{array}{r}-0.019 * \star \star \\
(0.007)\end{array}$ & $\begin{array}{r}-0.017^{\star *} \\
(0.007)\end{array}$ \\
\hline Profit & & & & & $\begin{array}{r}0.000 \text { *** } \\
(0.000)\end{array}$ \\
\hline Female * profit & & & & & $\begin{array}{r}0.000 * \star * \\
(0.000)\end{array}$ \\
\hline No. of observations & $5,751,561$ & $5,523,965$ & $2,160,245$ & $5,725,933$ & $5,523,360$ \\
\hline $\mathrm{R}^{2}$ & 0.909 & 0.909 & 0.97 & 0.920 & 0.909 \\
\hline
\end{tabular}

Note: standard errors in parentheses clustered at the level of the firm. Additional controls include age and age squared. ${ }^{* \star} p<0.01,{ }^{* *} p<0.05,{ }^{*} p<0.1$.

Source: authors' construction based on SARS data (National Treasury and UNU-WIDER 2019a, b).

\section{Conclusion}

Persistent inequality in opportunities and incomes raises important challenges for societies. Understanding the underlying drivers of such distributional issues is key to addressing them. In this paper we examine the GWG, a major driver of overall wage inequality, and how it links to trade. In particular, we show that trading firms, which account for more than two-thirds of employment in South African manufacturing, raise gender inequality substantially, as they exhibit a GWG that is four percentage points higher than the GWG of firms that operate only domestically. This additional wage gap related to trade remains present and statistically significant even when we control for different sets of fixed effects that account for unobserved worker and firm heterogeneity.

To facilitate the development of policies to counter this trend, we examine the channels behind it. We find preliminary evidence that this behaviour is driven by the demands that trading places on workers in terms of flexibility. Employees of firms with foreign customers or suppliers need to work at unusual hours and travel frequently. This places employees who are less flexible at a 
disadvantage when it comes to reaping the benefits of trade, such as the wage premium paid by trading firms. Since women often need to shoulder a larger share of domestic responsibilities than men, especially with respect to child-rearing, they are perceived to be less flexible. Consequently, we show that trading firms exhibit a larger wage in particular for women below the age of 45that is, for women more likely to have school-age children. We also show that the same mechanism seems to apply to foreign-owned companies in South Africa. However, further tests on this channel are inconclusive, calling for further research into this question.

The findings from this paper highlight how the gains from trade and foreign investment can be magnified for South Africa if they are embedded in an inclusive approach. In particular, our findings suggest that government or firm policies that reduce perceived flexibility gaps between men and women have the potential to reduce inequality and spread the gains from trade more evenly. Examples of such policies could relate to the provision of childcare institutions or subsidies, a more even distribution between parents of parental leave, or support for technologies such as videoconferencing that can reduce the need for travel.

\section{References}

Aguayo-Tellez, E., J. Airola, C. Juhn, and C. Villegas-Sanchez (2014). 'Did Trade Liberalization Help Women? The Case of Mexico in the 1990s'. In S.W. Polachek and K. Tatsiramos (eds), New Analyses of Worker Well-Being. Bingley, West Yorkshire: Emerald Publishing Group. https://doi.org/10.1108/S0147-9121(2013)0000038001

Artecona, R., and W. Cunningham (2002). 'Effects of Trade Liberalization on the Gender Wage Gap in Mexico'. Policy research report on gender and development working paper series 21 . Washington, DC: World Bank.

Becker, G.S. (1957). The Economics of Discrimination. Chicago: The University of Chicago Press.

Ben Yahmed, S. (2017). 'Gender Wage Discrimination and Trade Openness. Prejudiced Employers in an Open Industry'. ZEW Discussion Paper 17-047. Mannheim: ZEW - Leibniz Centre for European Economic Research. Available at: http://ftp.zew.de/pub/zew-docs/ dp/dp17047.pdf (accessed 18 February 2020).

Berik, G., Y. Van der Meulen Rodgers, and J.E. Zveglich (2004). 'International Trade and Gender Wage Discrimination: Evidence from East Asia'. Review of Development Economics, 8(2): 237-54. https://doi.org/10.1111/j.1467-9361.2004.00230.x

Bernard, A.B., J.B. Jensen, and R.Z. Lawrence (1995). 'Exporters, Jobs, and Wages in US Manufacturing: 1976-1987'. Brookings Papers on Economic Activity Microeconomics, 1995(1995): 67-119. https://doi.org/10.2307/2534772

Bernard, A.B., J.B. Jensen, S.J. Redding, and P.K. Schott (2007). 'Firms in International Trade'. Journal of Economic Perspectives, 21(3): 105-30. https://doi.org/10.1257/jep.21.3.105

Bezuidenhout, C., C. Janse van Rensburg, M. Matthee, and V. Stolzenburg (2019). 'Trading Firms and the Gender Wage Gap: Evidence from South Africa'. Agenda, 33(4): 79-90. https://doi.org/10.1080/10130950.2019.1677162

Bezuidenhout, C., M. Matthee, and N.A. Rankin (2018). 'Employment and Wage Premiums in South African Manufacturing Exporters: Firm-Level Evidence'. Development Southern Africa, 36(5): 632-50. https://doi.org/10.1080/0376835X.2018.1544483

Bhorat, H., and S. Goga (2013). 'The Gender Wage Gap in Post-Apartheid South Africa: A Reexamination'. Journal of African Economies, 22(5): 827-48. https://doi.org/10.1093/jae/ ejt008

Black, S.E., and E. Brainerd (2004). 'Importing Equality? The Impact of Globalisation on Gender Discrimination'. Industrial and Labor Relations Review, 57(4): 540-59. https://doi.org/10.2307/4126682 
Boler, E., B. Javorcik, and K.H. Ulltveit-Moe (2018). 'Working across Time Zones: Exporters and the Gender Wage Gap. Journal of International Economics, 111(C): 122-33. https:// doi.org/10.1016/j.jinteco.2017.12.008

Ebrahim, A., and K. Lilenstein (2019). 'Gender and the South African Labour Market: Policy Relevant Research Possibilities using South African Tax Data’. WIDER Working Paper 2019/31. Helsinki: UNU-WIDER. https:/ / doi.org/10.35188/UNU-WIDER/2019/665-4

Fafchamps, M. (2009). 'Human Capital, Exports, and Earnings'. Economic Development and Cultural Change, 58(1): 111-41. https:// doi.org/10.1086/604721

Galor, O., and D.N. Weil (1996). 'The Gender Gap, Fertility, and Growth'. American Economic Review, 86(3): $374-87$.

Hummels, D., J. Munch, and C. Xiang (2016). 'Offshoring and Labor Markets'. NBER Working Paper 22041. Cambridge, MA: NBER (National Bureau of Economic Research). https://doi.org/10.3386/w22041

Irarrazabal, A., A. Moxnes, and K.H. Ulltveit-Moe (2013). 'Heterogeneous Firms or Heterogeneous Workers? Implications for the Exporter Premium and the Impact of Labor Reallocation on Productivity'. Review of Economics and Statistics, 95(3): 839-49. https:/ /doi.org/10.1162/REST_a_00285

Juhn, C., G. Ujhelyi, and C. Villegas-Sanchez (2014). 'Men, Women, and Machines: How Trade Impacts Gender Inequality'. Journal of Development Economics, 106(C): 179-93. https://doi.org/10.3386/w18106

Klein, M.W., C. Moser, and D.M. Urban (2013). 'Exporting, Skills and Wage Inequality'. Labour Economics, 25(C): 76-85. https://doi.org/10.1016/j.labeco.2013.03.005

Kodama, N., B. Javorcik, and Y. Abe (2018). 'Transplanting Corporate Culture across International Borders: Foreign Direct Investment and Female Employment in Japan'. The World Economy, 41(5): 1148-65. https:// doi.org/10.1111/twec.12612

Kollamparambil, U., and A. Razak (2016). 'Trends in Gender Wage Gap and Discrimination in South Africa: A Comparative Analysis across Races'. Indian Journal of Human Development, 10(1): 49-63. https://doi.org/10.1177/0973703016636446

Lepelle, R., L. Edwards, and M. Leibbrant (2017). 'Trade Effects on Gendered Labour Market Outcomes in Post-Apartheid South Africa'. Paper presented at the Bi-annual Conference of the Economic Society of South Africa, Rhodes University, Grahamstown, South Africa, 30 August to 1 September.

Magda, I., and K. Salach (2019). 'Gender Pay Gap Patterns in Domestic and Foreign-Owned Firms'. IBS Working Paper 05/2019. Warsaw: IBS (Institute for Structural Research).

Martins, P., and L.D. Opromolla (2011). 'Why Ex(im)porters Pay More: Evidence from Matched FirmWorker Panels'. IZA Discussion Paper 6013. Bonn: IZA (Institute of Labor Economics). Available at: $\quad$ https://www.iza.org/publications/dp/6013/why-eximporters-pay-more-evidence-frommatched-firm-worker-panels (accessed 18 February 2020).

McKinsey Global Institute (2015). The Power of Parity: How Advancing Women's Equality Can Add \$12 Trillion To Global Growth. McKinsey \& Company. Available at: https://www.mckinsey.com/ featured-insights/employment-and-growth/how-advancing-womens-equality-can-add-12-trillion-toglobal-growth (accessed 18 February 2020).

Mincer, J. (1974). Schooling, Experience and Earnings. New York: NBER.

Mosomi, J. (2019). 'Distributional Changes in the Gender Wage Gap in the Post-Apartheid South African Labour Market'. WIDER Working Paper 2019/17. Helsinki: UNU-WIDER. https://doi.org/10.35188/UNU-WIDER/2019/651-7

Muller, C. (2009). 'Trends in the Gender Wage Gap and Gender Discrimination among Part-Time and FullTime Workers in Post-Apartheid South Africa'. Working Paper 124. Durban: University of KwaZuluNatal. 
National Treasury and UNU-WIDER (2019a). CIT-IRP5 Firm Panel 2008-2017 [dataset]. Version 3.4. Pretoria: South African Revenue Service [producer of the original data], 2018. Pretoria: National Treasury and UNU-WIDER [producer and distributor of the harmonized dataset].

National Treasury and UNU-WIDER (2019b). IRP5 2008-2017 [dataset]. Version 0.6. Pretoria: South African Revenue Service [producer of the original data], 2018. Pretoria: National Treasury and UNUWIDER [producer and distributor of the harmonized dataset].

National Treasury and UNU-WIDER (2020). CIT-IRP5 Firm Panel 2008-2017 [dataset]. Version 3.5. Pretoria: South African Revenue Service [producer of the original data], 2018. Pretoria: National Treasury and UNU-WIDER [producer and distributor of the harmonized dataset].

Ntuli, M. (2007). 'Exploring Gender Wage "Discrimination" in South Africa, 1995-2004: A Quantile Regression Approach'. IPC Working Paper 56. Ann Arbor, MI: International Policy Center (IPC), Gerald R. Ford School of Public Policy, University of Michigan.

Pieterse, D., C.K. Friedrich, and E. Gavin (2016). 'Introduction to the South African Revenue Service and National Treasury Firm-Level Panel’. WIDER Working Paper 2016/42. Helsinki: UNU-WIDER. https://doi.org/10.35188/UNU-WIDER/2016/085-0

Rankin, N., and V. Schöer (2013). 'Export Destination, Product Quality and Wages in a Middle-Income Country. The Case of South Africa'. Review of Development Economics, 17(1): 64-73. https://doi.org/10.1111/rode.2013.17.issue-1

Sauré, P., and H. Zoabi (2014). 'International Trade, the Gender Wage Gap and Female Labor Force Participation'. Journal of Development Economics, 111(C): 17-33. https://doi.org/10.1016/j.jdeveco.2014.07.003

Schank, T., C. Schnabel, and J. Wagner (2007). 'Do Exporters Really Pay Higher Wages? First Evidence from German Linked Employer-Employee Data'. Journal of International Economics, 72(1): 52-74. https:/ / doi.org/10.1016/j.jinteco.2006.08.004

Seguino, S. (1997). 'Gender Wage Inequality and Export-Led Growth in South Korea'. Journal of Development Studies 34(2): 102-32. https:// doi.org/10.1080/00220389708422513

Tang, H., and Y. Zhang (2017). 'Do Multinationals Transfer Culture? Evidence on Female Employment in China'. CESifo Working Paper 6295. Munich: CES (Centre for Economic Studies) and IFO (Institute for Economic Research). Available at: https://www.cesifo.org/ en/publikationen/2017/working-paper/do-multinationals-transfer-culture-evidence-femaleemployment (accessed 18 February 2020).

Thurlow, J. (2006). 'Has Trade Liberalization in South Africa Affected Men and Women Differently?' DSGD Discussion Paper 36. : Development Strategy and Governance Division (DSGD), International Food Policy Research Institute (IFPRI). Available at: https://www.ifpri.org/publication/has-trade-liberalization-south-africa-affected-men-and-womendifferently (accessed 8 July 2020).

UNU-WIDER (2020). 'World Income Inequality Database-WIID'. Available at: https://www.wider.unu.edu/database/wiid (accessed 8 July 2020).

Vahter, P., and J. Masso (2019). 'The Contribution of Multinationals to Wage Inequality: Foreign Ownership and the Gender Pay Gap'. Review of World Economics, 155(1): 105-48. https://doi.org/10.1007/s10290-018-0336-2

WBG (World Bank Group) and WTO (World Trade Organization) (2020). Women and Trade: The Role of Trade in Promoting Gender Equality. Washington, DC, and Geneva: WBG and WTO.

World Bank (2019). 'World Development Indicators'. https://databank.worldbank.org/ reports.aspx?source $=$ world-development-indicators (accessed on 29 September 2019).

WTO (2019). 'Aid for Trade Global Review 2019: "Supporting Economic Diversification and Empowerment". Geneva: W'TO. Available at: 
https://www.wto.org/english/tratop_e/devel_e/a4t_e/gr19_e/gr19programme_e.htm (accessed 18 February 2020). 


\section{Appendix}

Table A1: Description of variables used in regressions

\begin{tabular}{|c|c|c|c|}
\hline Variable & $\begin{array}{l}\text { Source } \\
\text { dataset }\end{array}$ & Definition & Calculation \\
\hline $\ln w_{i j s t}$ & $\begin{array}{l}\text { CIT- } \\
\text { IRP5 } \\
\text { panel }\end{array}$ & $\begin{array}{l}\text { The log of the monthly wage of } \\
\text { worker } i \text { of firm } j \text { in industry } s \text { at } \\
\text { time } t \text {. The industry variable is } \\
\text { derived from the } \\
\text { 'c_isic4_profcode_2d' variable. }\end{array}$ & $\begin{array}{l}\text { Monthly income per employee was calculated by } \\
\text { dividing the income by the number of days worked } \\
\text { to get the daily wage equivalent. The daily wage } \\
\text { equivalent was then multiplied by } 30 \text { to get the } \\
\text { monthly wage equivalent. }\end{array}$ \\
\hline fem $_{i}$ & IRP5 & $\begin{array}{l}\text { A dummy variable equal to } 1 \text { for } \\
\text { female workers. }\end{array}$ & 0 or 1. \\
\hline $\operatorname{trade}_{j t}$ & $\begin{array}{l}\text { CIT- } \\
\text { IRP5 } \\
\text { panel }\end{array}$ & $\begin{array}{l}\text { A dummy variable equal to } 1 \text { if the } \\
\text { firm imports, exports, or does both } \\
\text { (in the case of non-exporting firms } \\
\text { this variable is } 0 \text { ). }\end{array}$ & $\begin{array}{l}0 \text { or } 1 . \text { Firms that traded less than ZAR } 10,000 \text { per } \\
\text { year were not defined as trading. }\end{array}$ \\
\hline$a g e_{i t} / a g e_{i t}^{2}$ & IRP5 & $\begin{array}{l}\text { The age (and age squared) of } \\
\text { worker } i \text { at time } t .\end{array}$ & $\begin{array}{l}\text { The IRP } 5 \text { certificates include information on a } \\
\text { worker's birth date from which their age could be } \\
\text { calculated. Age was limited to those between } 15 \\
\text { and } 65 \text {. }\end{array}$ \\
\hline foreign $_{j t}$ & $\begin{array}{l}\text { CIT- } \\
\text { IRP5 } \\
\text { panel }\end{array}$ & $\begin{array}{l}\text { A dummy variable that captures } \\
\text { whether a firm } j \text { is foreign-owned or } \\
\text { not at time } t \text {. }\end{array}$ & $\begin{array}{l}\text { The variable is set to } 1 \text { if the ultimate holding } \\
\text { company is a foreign firm. All other observations, } \\
\text { including missing observations, were set to } 0 .\end{array}$ \\
\hline profit $_{j t}$ & $\begin{array}{l}\text { CIT- } \\
\text { IRP5 } \\
\text { panel }\end{array}$ & $\begin{array}{l}\text { The inverse of the profitability of } \\
\text { firm } j \text { at time } t \text {. }\end{array}$ & $\begin{array}{l}\text { The profitability variable is calculated as a ratio of } \\
\text { the firm's cost of sales to its sales. The cost of sales } \\
\text { is as per the accounting income statement. It is } \\
\text { calculated by taking the finished goods in the firm's } \\
\text { beginning inventory plus the cost of goods } \\
\text { manufactured during the accounting period minus } \\
\text { the cost of finished goods in ending inventory. }\end{array}$ \\
\hline
\end{tabular}

Source: authors' construction based on SARS data (National Treasury and UNU-WIDER 2019a, b).

Table A2: Summary statistics

\begin{tabular}{crrrr}
\hline Variable & Minimum & Maximum & Mean & Standard deviation \\
$\ln w_{i j s t}$ & -2.5014 & 19.9338 & 8.8683 & 1.1889 \\
fem $_{i}$ & 0 & 1 & 0.3244 & 0.4681 \\
trade $_{j t}$ & 0 & 1 & 0.696 & 0.46 \\
age $_{i t}$ & 15 & 64 & 38.3613 & 10.9396 \\
age $_{i t}^{2}$ & 3.873 & 8 & 6.1308 & 0.8802 \\
foreign $_{j t}$ & 0 & 1 & 0.1305 & 0.3369 \\
profit $_{j t}$ & -889.2 & $13,753.9$ & 0.7163 & 31.8358
\end{tabular}

Source: authors' construction based on SARS data (National Treasury and UNU-WIDER 2019a, b). 